\title{
A Discussion of New Test-type Reform of CET-4 and College English Teaching
}

\author{
Yi Lu \\ Jilin Business and Technology College, \\ No.1666 Calun Lake Street, Changchun \\ Jilin Province, China. \\ luyi0820@163.com
}

\author{
Mu Sun \\ Changchun University of Science and Technology, \\ No.7089 Weixing Road, Changchun \\ Jilin Province, China. \\ 172792256@qq.com
}

\begin{abstract}
In recent years, there are some reforms in the CET-4, and the latest one in Dec. 2015 has made great changes in the listening test. These reforms change the CET-4 from a content-center test to an ability-center test. The aim of the reform is to cultivate students' comprehensive language application skills. This paper will discuss the existed problems in college English teaching, and the latest reform of CET-4, and give suggestions on how to meet the ability requirements of new CET-4. The concrete measures are: we must take students as the center in classroom teaching; use communicative approach to cultivate communicative ability; strengthen the feedback function of CET4 on daily teaching; carry out the separation of teaching and testing, at last, we can use multi-media to enrich language environment to attract students' interests to learn.
\end{abstract}

Keywords-college English teaching, reform, application skills, communicative ability

\section{INTRODUCTION}

College English Test, Band Four (CET 4) has a close relation with college English teaching. It Improves the students' enthusiasm and autonomy of learning, and improves the teaching quality to some extent. The relationship between CET-4 and college English teaching is means and purpose. Teaching is foremost, and test is served for teaching. There are some wrong views about teaching and testing in college English teaching, which led to the dissimilation between CET4 and college English teaching. Some teachers take CET-4 as the teaching object, and all their teachings are served for the test. Under this teaching model, students only get some skills for tests, but no improvement in their abilities for reading, listening, speaking, writing and translation. They lost interests in learning English

\section{PROBLEMS IN THE COLLEGE ENGLISH TEACHING UNDER THE INFLUENCE OF CET-4}

\section{A. Teachers' and Students' Pressure from The Passing of CET-4}

Firstly, there are some views on the teaching concepts. CET-4 is a national exam, and it can objectively and accurately reflect the English teaching levels of colleges in a certain degree. But some colleges seek for the high passing rate, so they connect the CET-4 passing with the academic degree, and they regulate if you cannot pass CET-4, you'll not get the academic degree, to promote students to get higher CET-4 marks. Teachers use their time and energy to study the exam outline and exam paper to get some example tips for students. Class hours are used for the practicing and explaining of CET4, which lead to the decrease of teaching quality for college English. The side-effects of going after the high passing rate one-sidedly reflect in the feeling of teachers and students and teaching effects. For teachers, they feel the pressure from the CET-4, and the passing of CET-4 is the achievements of their work, some colleges even connect the passing of CET-4 with teachers' promotion and academic titles. Many English said, they had no time to do the creative teaching research under the high pressure of CET-4, and they serve all their teaching for CET-4. For the students, they have the fear for graduation if they cannot pass CET-4. So maybe they pass CET-4 at last, but their English level has no improvement and they already lost the interests for learning English.

\section{B. The Weighing of Certificate of CET-4 Is Too High, So It Triggers Abnormal Effects.}

Besides the education branch's leading function, more social functions also play a great role in the CET-4 hot. College English test is always regarded as an objective description of English level of college students. [1] So far, it is the only exam which has wide-spread recognition and authority. But there should be more dimensions for the evaluation of students' language level and skills. Students who get high CET-4 marks may not be speak frequently, or have the application ability. Just a high CET-4 mark does not say much. It is also unfair for students who pass CET-4 have better and more opportunities than those who don't.

\section{The Old Teaching Contents and Teaching Models}

For a long time, deaf and dumb English is the biggest problem for college English teaching. The traditional English class teaching emphasizes the explanations of grammar, but thinks little of language application ability. Lacking language application ability is the biggest problem for the current college students. Spoon-fed teaching model makes no communication between teachers and students. [2]

For the teaching contents, most colleges in the whole nation just have several teaching materials, they are authoritative and scientific, but they cannot meet the needs of students who come from all levels and all types colleges. The updating period of 
teaching material is long, and the updating speed is very low. [3] The modern society develops fast, and there are great changes in some countries' cultural background, views of value, people's thinking patterns, behavior rules and language habits. The development of technology brings more new words. So the old teaching contents can't provide necessary help for students to learn the non-verbal cultural background in British and American culture. [4]

\section{The Language Points for Testing Are Difficult and Peculiar}

Students always complain that the questions in CET-4 are very difficult, and someone asks the foreign teachers for help, but for the standard answers, foreign can't make it of all. Compared with the Chinese teachers, foreign teachers always make their class lively, and the contents are practical, and the interaction between teachers and students is very good. But those students sometimes cannot get good results in the CET-4, and the reason is that the testing points of CET-4 didn't emphasize the testing of students' language application ability.

In addition, the multiple choice of standardized test is not good for the cultivation of students' creativity. [5] Some students even recite some sample writings for the writing part, so when doing the write part, students don't write a word of their own, what they write down is just other people's words. Although many students get the certificate of CET-4 at last, they still don't have the English application ability. They still cannot read the English materials which are related to their majors, and they still cannot know the latest foreign information by using English. The aims for college students to learn English are mainly for communication, written or oral, and the ability to understand some original materials related to their majors. If the students want to do a further and deeper research in his major, he must have good reading skills of the original materials, which are mainly written in English.

\section{THE NEW TEST-TYPE REFORM OF CET-4 AND THE PROBLEMS EXISTED IN COLLEGE ENGLISH TEACHING}

The Exam Committee has always been reforming those years. The total marks are changed to 710, and above 425 means pass. In Dec. 2013, the new test type for CET-4 began to use. It has a more reasonable collocation of subjective and objective questions, and adds a proportion of subjective questions, and pays more attention to testing students' language application skills. In Dec. 2015, there was a big change in the listening test. The adjustment cancelled short conversation listening and passage dictation, and added news passage listening. The news dictation part will be difficult for students, there will be a great many of proper words and formal usage, and the topics are not about campus and life-related, which they are very familiar. The topics will focus on the politics of current events and social hot issues. [6] It will test more students' real application skills. In the sample test, all the news passages are from BBC, so in the daily teaching, we should add some teaching contents of the listening of VOA and BBC, and help students form a habit to read foreign newspapers and listen to or watch foreign news. The new CET-4 paper structure is listed as follow, see Table 1.

TABLE I. THE PAPER STRUCTURE OF NEW CET-4

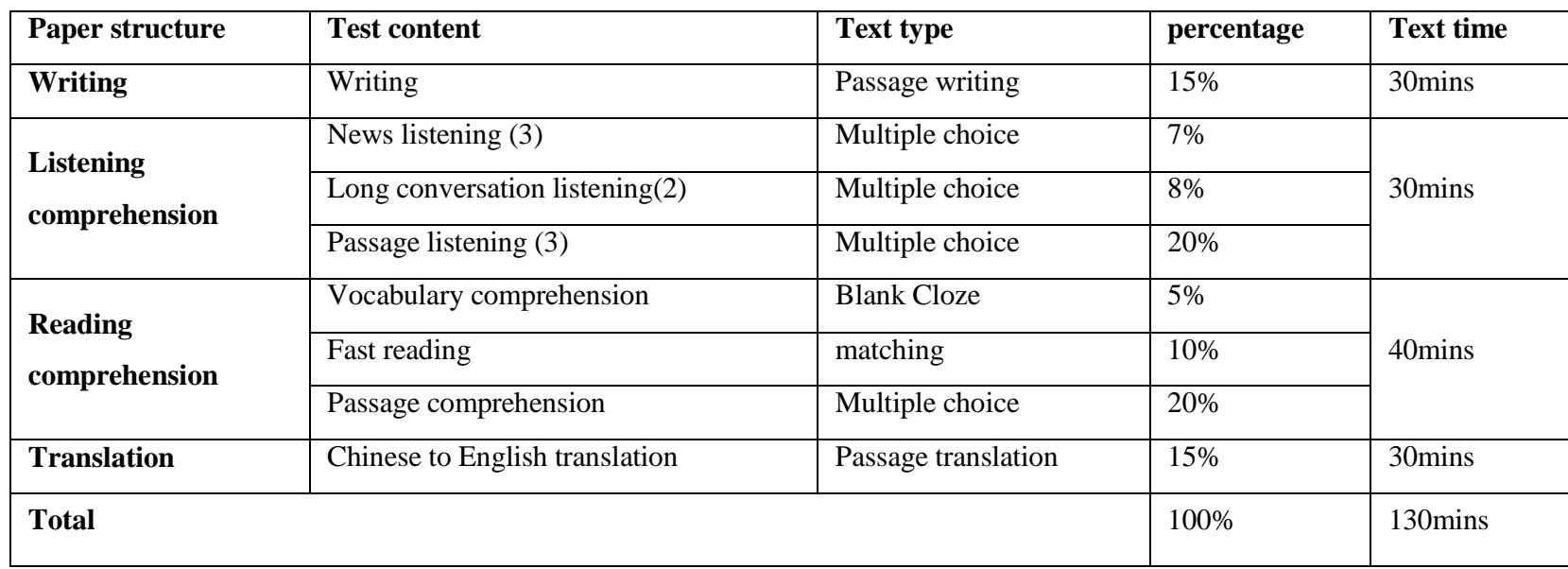

The reading comprehension part includes a long passage and three detailed readings. It tests students' reading comprehension ability from different levels, including the comprehension of main idea of passage and paragraph, the integrated analysis and the ability to infer word meaning. The long passage has 1000 words or so, and the reading speed should be 100 words per minute. There are ten sentences which are questions after the passage, and all the sentences come from the paragraph in the passage, and students just need to match. The translation part tests students to use English to express the contents which carried in Chinese, and the contents of translation involve Chinese history, culture, economy and social development, etc.

As the new test type starts to use, college English teachers will face new challenges, how to improve college students' English communication skills and how to cultivate the interdisciplinary and high-quality talents to adapt to the social development. The listening part changed a lot, and the new passage is added. The news all comes from VOA and BBC, which is very difficult for most students. The test is changed from content-oriented to ability-oriented. 
The traditional teaching models and teaching methods cannot satisfy the increasingly evolving teaching needs. In the former teaching models, teachers teach the textbooks and the study is exam-oriented, and teachers are the center of teaching, while students are just passive receivers and listeners. The teaching effects are not good. The modern teaching models emphasize we should take students as the main body, and in the practical teaching, it also verifies that teaching effects are better and more effective only by taking students as the main body. In this model, teachers are the transmitters of the knowledge and communicators of students' interaction. Here are some suggestions on how to create teaching models, improve the teaching quality and cultivate students' practical application ability.

\section{THE SUGGESTIONS ON MEETING THE REQUIREMENTS OF NEW CET-4 IN COLLEGE ENGLISH TEACHING}

\section{A. Take The Students As the Center in Teaching}

The students-centered idea springs from John Dewey, an American children psychologist and educationist. Dewey strongly opposed the teaching method of taking teachers as the center, and he also opposed the spoon-feeding in class. He proposed freeing children's mind, and organizing the teaching contents children-centered, and to develop children's subjective initiative. [7] His central idea is learning while thinking, participating and doing. Gradually his view was adapted into all levels of students, and its distinguished feature is under teacher's leading guidance, playing student's main body role fully. English is a practical lesson, and students can acquire the language skills by actual drilling. It needs teachers bear in minds the idea of students-centered to help students accept knowledge actively instead of receiving them passively.

\section{B. Use Communicative Approach in Teaching}

Communicative Approach was a school of foreign language teaching methodology based on the theories of Hymes and M.A.K.Halliday. The communicative holds the view that the aim for language teaching is to cultivate students' skills of using target language to communicate. [8] The contents for language learning should include not only language structure, but also the useful expressions which express ideas and functions. The communicative skills include grammar communicative skills, social language skills, discourse skills and strategic skills. The Communicative Approach teaches language as a communicative skill, and takes the textbooks as the clues. It is a teaching model which develops students' listening, speaking, reading and writing skills based on language functions and communication needs. Its purpose is to let students learn the language, and use language to communicate in real situations.

Recently, the task for college English teaching is to cultivate students' language comprehensive application skills while Communicative Approach focuses on the cultivation of communicative skills. For example, we can organize students perform the story of the text on the platform in groups. Before the performance, teachers give different requirements according to students' levels, and students will do it well after good preparations although it's a little bit difficult.

\section{Strengthen the Feedback Function of CET-4 on Daily Teaching, and Improve the Teaching Quality.}

To improve the quality of a test, we should mainly raise its credibility and validity. From the development of language test, the credibility and validity are usually contradictory. The high credibility question type, such as multiple choices, is low validity. The high validity question types, such as composition, oral test, are low credibility. So it is difficult to ensure the objective and consistent of evaluation standard. Besides, for the constraints of testing measures, the result of language test is periodical, it can only give an evaluation of students' skills when teaching finished. So the language test is only a periodical evaluation, it can't improve students' actual language skills, and it can't replace teaching. Increase the constructed response items which can directly evaluate students' application abilities, and decrease number and weight of the selected response items. We should constantly adjust the learning process according to the results of testing. After the completion of teaching, the test also gives the correct evolution on students' achievements, and makes a perfect connection of high credibility and validity. [9]

\section{Establish College English Test and Teaching Connection Network, and Carry out the Separation of Teaching and Testing.}

In order to feedback the rich information of CET-4 to the frontline of teaching, and popularize the knowledge of language test, and strengthen the connection of testing and teaching, we should establish a network of CET-4 teaching and learning. In the long run, with the development of language testing science and the improvement of testing measures, the use of item response theory to construct question bank, the exploitation of self-adaptive testing system, and the application of multi-media technology can connect studying and testing, and make the learning process turn a self-assessment process. We should also separate the teaching from testing, after the separation, the test is the level test which faces the whole society, and makes it have the same authority as TOEFL and IELTS, and provides a credible test achievements to the society. In this way, college English teaching can walk out the wrong region of exam-oriented education, and practice quality education to improve the teaching quality.

\section{E. Use Multimedia to Enrich Language Environment}

With the development of society, the styles for English teaching changed greatly. Multimedia teaching plays a more and more important role. Multimedia teaching has many features, such as vast teaching information, vivid images, and strong visual appeal. We can play the English classical videos, and make students imitate, and motivate students' participation in the class. Besides, multi-media can stimulate students' aural and visual sense, make their attention focused and improve the study efficiency in class.

English teachers are not just the designers of English teaching, but also the researchers. With the constant development of modern education technology, the CAI (Computer-aided Instruction) technology can put the sounds, words, images and video information together, and present the historical events, people and place to the students with the 
vivid images. It can introduce the language background information, and give a lively language environment; all those will give students a deep impression, and promote the enthusiasm of learning English. The popularization of internet gives a great convenience to the spread of multimedia teaching materials. [10]

In the new reform, listening is the most difficult part, because it changed a lot. The news listening - a test-type of Band- 4 and Band-8 is removed in the new CET-4. In the news listening, there will be plenty of proper nouns and formal usage and the topics will be about current politics and hot social problems, but not about campus and life which students are familiar with. So in the classroom, we can make the best use of multi-media to train students' listening skills, such as, watching the latest American news programs, talk shows and movies. Cultivate students' interests to watch and listen to the original materials and materials made by native speakers.

\section{SUMMARY}

From the new test-type reform of CET-4, we can see that the target of college English teaching is more inclined to the cultivation of students' comprehensive abilities, and helps students be the inter-disciplinary talents. As college English teachers, we should carry out the aims in everyday teaching and help students get better language skills.

\section{REFERENCES}

[1] Hu Chundong, English methodology, Beijing Higher Education Press, pp.28-29, 1990.

[2] $\mathrm{Li} \mathrm{Yu}, \mathrm{An}$ analysis of communicative approach in the foreign language teaching, Changchun University of Science and Technology Journal, Vol. 12, pp. 78-79, 2012.

[3] Cai Jigang, The CET reform compared with the reform of STEP in Japan, Foreign Language Learning Theory and Practice, Vol. 1, pp. 3435, 2006.

[4] Cai Jigang, College English teaching, Fudan University Press, pp. 56-59, 2006.

[5] Ming Doudou, The new writing strategies for new CET, New Oriental English, vol. 3, pp. 37-38, 2007.

[6] The application research of the flipped classroom model in college English teaching, Scientific Chinese, Vol. 12, pp. 69-71, 2016.

[7] The reform research of CET-4 and CET-6, Xiamen University, pp. 2325, 56-57, 2008.

[8] Guo Wenying, The reform research of the exam system in CET-4, Suzhou University, pp. 56-58, 2014.

[9] Zeng Junjie, The ideas and implement of communicative approach, Read and Write, Vol. 3, pp. 25-26, 2013.

[10] A discussion on the new type of CET-4 and college English teaching, Youth Writers, Vol. 11, 200-201, 2013. 